\title{
Patterns of Cystine Reduction by Fibroblasts from Normal and Cystinotic Children
}

\author{
BEATRICE STATES,(2i) DOROTHY HARRIS, AND STANTON SEGAL \\ Division of Biochemical Development and Molecular Diseases, Children's Hospital of Philadelphia, and \\ Departments of Pediatrics and Medicine, University of Pennsylvania School of Medicine, \\ Philadelphia, Pennsylvania, USA
}

\begin{abstract}
Summary
The possibility that the enzymatic reduction of cystine involves a multi-enzyme system led to re-evaluation of cystine reduction by fibroblasts from normal and cystinotic patients. LineweaverBurk plots of data with extracts of a normal cell line, representative of seven normal cell lines, under conditions of increasing cystine with variable levels of reduced glutathione (GSH) resulted in a two-limbed curve above $100 \mu N 1$ cystine. Two cell lines from children with nephropathic cystinosis containing 1-6 $\mu$ mol half-cystine/g protein gave a family of curves similar to those of the normal. With six fibroblast lines containing more than $6 \mu \mathrm{mol}$ half-cystine/g protein, increasing cystine resulted in a family of lines without two-limbed curves. Plots of the data as activity against increasing cystine concentrations at ratios of cystine to GSH of $1: 2$ and $1: 1$ showed that two of the three lines from cystinotic subjects reduced cystine at a faster rate than the normal line. The third line from a cystinotic patient reduced cystine at a slightly slower rate when the substrate concentration in the assay was less than $80 \mu M$ cystine. When the cystine to GSH ratio was maintained at $2: 1$, normal cells showed a linear increase in the rate of cystine reduction up to $100 \mu \mathrm{M}$ cystine, no increase in the rate between $100 \mu N 1$ and $200 \mu M$ cystine, and an increase again when the concentration of cystine was raised above $200 \mu \mathrm{M}$. Such a stepwise phenomenon was absent with six cell lines containing more than $6 \mu \mathrm{mol}$ half-cystine/g cellular protein. A possible mechanism of control of cystine reduction is discussed.
\end{abstract}

\section{Speculation}

A defect in the reductive mechanism of cystine metabolism has been suggested as a cause of cystinosis. Plots of the rate of cystine reduction with increasing cystine concentration at a cystine to glutathione ratio of $2: 1$ showed a pattern typical of a multiple enzyme system with extracts from normal cells. Since such a two-step configuration is not observed with extracts from cells containing high levels of intracellular cystine, the control of cystine reduction inherent in the complex multienzyme system in normal cells may be absent, altered, or defective in cells ftom cystinotic patients. This difference in the pattern of cystine reduction by cells from cystinotic patients could be due to either a primary or a secondary factor resulting in sequestration of cystine in cystinosis. However, many additional kinetic parameters, starting with delineation of the multistep enzyme system, remain to be investigated before a judgment can be made as to the role of this abnormal pattern in the storage of cystine by cells from cystinotics.

Cystinosis is a recessively inherited disorder characterized by accumulation of cystine in many tissues of the body. Accumulation of cystine within the kidney is associated with renal failure and death before puberty. Although the symtomatology associ- ated with abnormal levels of intracellular cystine has been well appreciated since early in this century, the defect responsible for this storage remains an enigma. With the discovery that both leukocytes and fibroblasts from cystinotic patients contain intracellular cystine levels approximately 80-100 times above normal, excellent model systems became available for study (17). Since a key step in cystine metabolism involves reduction to cysteine, the possibility of a defect in the reductive mechanism was examined by Tietze et al. (24), using leukocytes, and Kaye and Nadler (6), using cultured fibroblasts. By the methods they employed, which measured cystine reduction indirectly by assessment of NADPH oxidation when coupled to the oxidized glutathione (GSSG) reductase reaction, no difference between cells from normal and cystinotic subjects was observed. In accordance with the postulate of Askelof et al. (1), we have considered the possibility that the enzymatic reduction of cystine involves a multienzyme system and have, therefore, re-evaluated cystine reduction by fibroblasts directly by quantitating the rates of cysteine formation. This has been done without the addition of exogenous GSSG reductase. Our results under varying cystine and GSH concentrations are the subject of this report.

\section{MATERIALS AND METHODS}

\section{CHEMICALS}

L-Cystine, cysteine-HCl, $N$-ethylmaleimide (NEM), nicotinamide adenine dinucleotide phosphate reduced tetrasodium salt (NADPH), GSH, and GSSG were purchased from Calbiochem, Los Angeles, Calif. L- $\left[{ }^{35} \mathrm{~S}\right]$ Cystine, with a specific activity of 105 $\mathrm{mCi} / \mathrm{mmol}$, was obtained from the Radiochemical Centre, Amersham, Bucks, UK. For purification, $0.5 \mathrm{mg} \mathrm{L-}\left[{ }^{35} \mathrm{~S}\right]$ cystine was coprecipitated twice with $15 \mathrm{mg}$ pure L-cystine by dissolving in $\mathrm{NaOH}$ and adjusting the $\mathrm{pH}$ to 4.5 with $\mathrm{HCl}$. After the second precipitation, the isolated $\mathrm{L}-\left[{ }^{35} \mathrm{~S}\right] \mathrm{cystine}$ was washed with $1 \mathrm{ml}$ cold $\mathrm{H}_{2} \mathrm{O}$, recentrifuged, and the pellet dried in vacuo. Liquifluor was purchased from New England Nuclear Corporation, Boston, Mass. Eastman Kodak thin layer cellulose plates and general AR grade reagents were purchased from Fisher Scientific Company, King of Prussia, Pa. Roller bottle equipment was supplied by Bellco, Vineland, N. J. Minimun Eagles medium (MEM), glutamine, and fetal bovine serum were purchased from Flow Laboratories, Rockville, Md. Scintillation vials were purchased from Packard Instrument Company, Downers Grove, Ill.

\section{CELLS}

Fibroblast lines, started from biopsies from cystinotic and normal children ranging from $1-11$ years old, were subcultured as previously described (21). For bulk production, cells were transferred from Brockway bottles to roller bottles which were incubated at $37^{\circ}$ on a roller bottle apparatus where the bottles turned 10 times/hr. Each bottle was gassed daily for 1 min with 95:5 compressed air- $\mathrm{CO}_{2}$. Refeedings were on the third and 
sixth days. At the time of passage into roller bottles, a $0.1-\mathrm{ml}$ fraction of each cell suspension was inoculated into yeast, mold, and bacterial broth media to check for possible contaminants. When the cells were confluent and in the stationary phase of growth, i.e., the seventh day, they were pooled as follows: the media in 50 roller bottles were removed, approximately $15 \mathrm{ml}$ cold MEM were added to each bottle, and the cells were scraped off the glass surface into the media with a special soft rubber scraper (Bellco). The cell suspensions were pooled and centrifuged for $6 \mathrm{~min}$ at $800 \times \mathrm{g}$. Each pellet was suspended in $5 \mathrm{ml}$ cold $\mathrm{Mg}-\mathrm{Ca}-$ free phosphate buffered saline (PBS), pH 7.4. The cells were recentrifuged for $6 \mathrm{~min}$ at $800 \times \mathrm{g}$ followed by two additional washings with $20 \mathrm{ml}$ cold PBS buffer, $\mathrm{pH} 7.4$. In the final step, the cells were suspended in $6 \mathrm{ml}$ cold $0.25 \mathrm{M} \mathrm{D}$-mannitol containing $2.5 \mathrm{mM}$ EDTA adjusted to pH 7.4 with $\mathrm{NaOH}$ and homogenized, using 20 strokes with the loose pestle and 10 strokes with a tight pestle in a 7-ml Dounce homogenizer made by Kontes Glass Co., Vincland, N. J. The suspension was centrifuged at $4^{\circ}$ in a Sorvall model RC2-B centrifuge for 6 min at $1,200 \times g$. The supernatant was centrifuged at $4^{\circ}$ for $20 \mathrm{~min}$ at $12,500 \times \mathrm{g}$, the pellet discarded, and the supernatant further spun at $105,000 \times g$ for $1 \mathrm{hr}$ in the Spinco model L ultracentrifuge. The $105,000 \times g$ supernatant fractions, assayed for protein by the method of Lowry et al. (8), were used as the standard enzyme preparation. All studies were performed immediately after protein assay and on the same day as the cells were fractionated (23). The cells used in these studies ranged from passage numbers 12 through 16 . Contamination of the high speed supernatant fraction with endogenous cystine in cells originating from cystinotics was found to be negligible, i.e., 0.15 nmol cystine/mg $105,000 \times g$ supernatant protein.

\section{ASSAY}

The incubation mixture consisted of $0.1 \mathrm{ml}$ high speed supernatant enzyme preparation, $0.1 \mathrm{ml} 0.25 \mathrm{M}$ D-mannitol with 2.5 mM EDTA, pH 7.4, $0.1 \mathrm{ml} 0.1 \mathrm{M}$ potassium phosphate buffer containing $2.5 \mathrm{mM}$ EDTA, $\mathrm{pH} 6.6$, and $10-\mu$ l additions of NADPH, GSH, and L- $\left[{ }^{35}\right.$ S $]$ cystine in a total volume of $0.33 \mathrm{ml}$. The final concentration of NADPH was $34 \mu \mathrm{M}$. GSH and L$\left[{ }^{35} \mathrm{~S}\right]$ cystine concentrations varied according to experimental design. For each experiment, $1 \mathrm{mg} \mathrm{L}-\left[{ }^{35}\right.$ S $]$ cystine plus $1 \mathrm{mg}$ carrier L-cystine were dissolved by addition of $0.1 \mathrm{ml} 0.5 \mathrm{~N} \mathrm{NaOH}$ and brought to $1 \mathrm{ml}$ with water. All cystine concentrations were prepared from such stock by dilution with $0.05 \mathrm{~N} \mathrm{NaOH}$.

The effects of $\mathrm{pH}$, incubation time, and amounts of enzymeprotein on the rate of cystine reduction were determined to minimize the contribution of nonenzymatic reduction. To accomplish this, the assay was conducted at $\mathrm{pH} 6.87$ inasmuch as the nonenzymatic contribution for subtraction from the total enzymatic-nonenzymatic reaction increased markedly above $\mathrm{pH}$ 7.0. The reduction of cystine was linear both for the first $10 \mathrm{~min}$ of incubation and up to $180 \mu \mathrm{g}$ enzyme protein. Moreover, the same linearity was observed with extracts from cells from normal and cystinotic subjects. Assay conditions, therefore, were set as follows: incubations were at a final $\mathrm{pH} 6.87$ at $30^{\circ}$ for $10 \mathrm{~min}$ with $160-180 \mu \mathrm{g}$ protein. The reaction was stopped by mixing for $0.5 \mathrm{~min}$ with $0.2 \mathrm{ml} 40 \mathrm{mM}$ NEM prepared in $0.01 \mathrm{M}$ potassium phosphate buffer, $\mathrm{pH} \mathrm{7.4,} \mathrm{to} \mathrm{form} \mathrm{the} \mathrm{NEM} \mathrm{adducts}$ of cysteine and unreacted GSH. Samples were deproteinized with $0.1 \mathrm{ml}$ of $25 \%(\mathrm{w} / \mathrm{v})$ trichloroacetic acid (TCA), mixed well, and placed in the cold to ensure complete protein precipitation before centrifugation for $20 \mathrm{~min}$ at $1,000 \times g$ in an International Centrifuge. Excess NEM and TCA were removed by extracting twice with $1-\mathrm{ml}$ portions of diethyl ether. All assays were run in triplicate with either a boiled tissue control or a control supplemented with $0.1 \mathrm{ml}$ of $0.25 \mathrm{M} \mathrm{D}$-mannitol +2.5 $\mathrm{mM}$ EDTA in place of boiled enzyme. Both controls gave comparable values for nonenzymatic reduction of cystine by GSH. Thin layer chromatography was in solvent B4 as described previously (9). The chromatographed samples were cut into 0.5 $\mathrm{cm}$ strips starting with $1.5 \mathrm{~cm}$ before the origin to $11.5 \mathrm{~cm}$ from the origin. Each strip was placed in a vial containing $2 \mathrm{ml}$ phosphor scintillator (Liquifluor) and radioactivity was determined by counting in a Packard liquid-scintillation spectrometer.

Reduction of cystine to cysteine was calculated as previously described (23). Lineweaver-Burk plots and $K_{m}$ and $V_{\max }$ values were determined using a programmable Monroe 1775 calculator. Intracellular free cyst(e)ine in cells from cystinotic and normal subjects was determined with the Beckman $120 \mathrm{C}$ amino acid analyzer (Beckman Instruments Inc., Fullerton, Calif., USA) as cescribed previously (21).

\section{RESULTS}

Studies of the effects of levels of cystine and glutathione on the rate of enzymatic cystine reduction revealed striking differences between cells originating from normal and cystinotic children. The Lineweaver-Burk plots in Figure $1 A$ show the effects and interactions of increasing cystine with variable levels of GSH by enzymes from a normal cell line which is representative of the seven normal cell lines studied. Below $100 \mu \mathrm{M}$ cystine, the plot is linear but above $100 \mu \mathrm{M}$ cystine, a two-limbed curve results, indicating the possibility of a multienzyme system with at least two $\mathrm{K}_{\mathrm{m}}$ and two $\mathrm{V}_{\text {max }}$ values. Two cell lines from children with nephropathic cystinosis containing 1-6 $\mu$ mol half-cystine/g cellular protein gave a family of curves similar to those of the normal in Figure $1 A$; however, the results of similar studies with four of the six cell lines of cystinotics with levels above $6 \mu \mathrm{mol}$ half-cystine/g protein show a pattern as seen in Figure $1, B$ and $C$. Figure $1 B$ is a lineweaver-Burk plot of cystine reduction by enzymes in the high speed supernatant fraction of a cell line with $14 \mu \mathrm{mol}$ intracellular half-cystine/g protein. This figure also represents the characteristic pattern obtained in experiments with another cell line which contained $10.8 \mu \mathrm{mol}$ half-cystine/g protein. These two cell lines have a slower rate of cystine reduction and have been observed to grow more slowly than other lines with high levels of intracellular cystine. Figure $1 C$ is another Lineweaver-Burk plot of results from a cell line with 13 $\mu \mathrm{mol}$ half-cystine/g protein. This plot is also the pattern of an additional cell line which contains $9 \mu$ mol half-cystine/g protein. Both of these cell lines reduce cystine more rapidly than normal cells. With all four of these cells, increasing cystine results in a family of lines without any two-limbed curves. (The other two lines studied with intracellular levels above $6 \mu \mathrm{mol}$ half-cystine/g protein are discussed below and the results are plotted in Figure $2, A$ and $B$.) The studies with normal cells suggest a sharp change in $\mathrm{K}_{\mathrm{m}}$ from $0.025 \mathrm{mM}$ for GSH with cystinc below 100 $\mu \mathrm{M}$ to $0.25 \mathrm{mM}$ for GSH at levels of cystine above $100 \mu \mathrm{M}$. Such a distinct 10 -fold increase in $\mathrm{K}_{\mathrm{m}}$ for GSH with a break at substrate levels of $100 \mu \mathrm{M}$ cystine is not observed with extracts from cell lines containing more than $6 \mu \mathrm{mol}$ half-cystine/g protein. All of the studies with extracts of cystinotic cells delineating these patterns were performed at least twice and the results with a given cell line were reproducible.

Figure $1, D$ and $E$, is of Lineweaver-Burk plots of the data obtained under conditions of constant GSH and varying cystine, using extracts of the same cell line depicted in Figure 1, $A$ and $B$, respectively. Over the range of cystine and glutathione studied, the apparent $\mathrm{K}_{m}$ of the crude multienzyme system is lower in normal lines when GSH is maintained between $75-100 \mu \mathrm{M}$. However, as shown in Figure $1 E$, the handling of cystine by enzymes in the high speed supernatant fraction from cells with a high intracellular cystine level appears to be unaffected by changes in the ratio of cystine to GSH.

A somewhat different pattern (Fig. $2 A$ ) for cystine reduction than described above was observed with a cell line obtained from a 6-month-old child before development of overt manifestations of cystinosis who was a sibling of the child whose cell cystine reduction data are shown in Figure $1 B$. The cells contained 7 

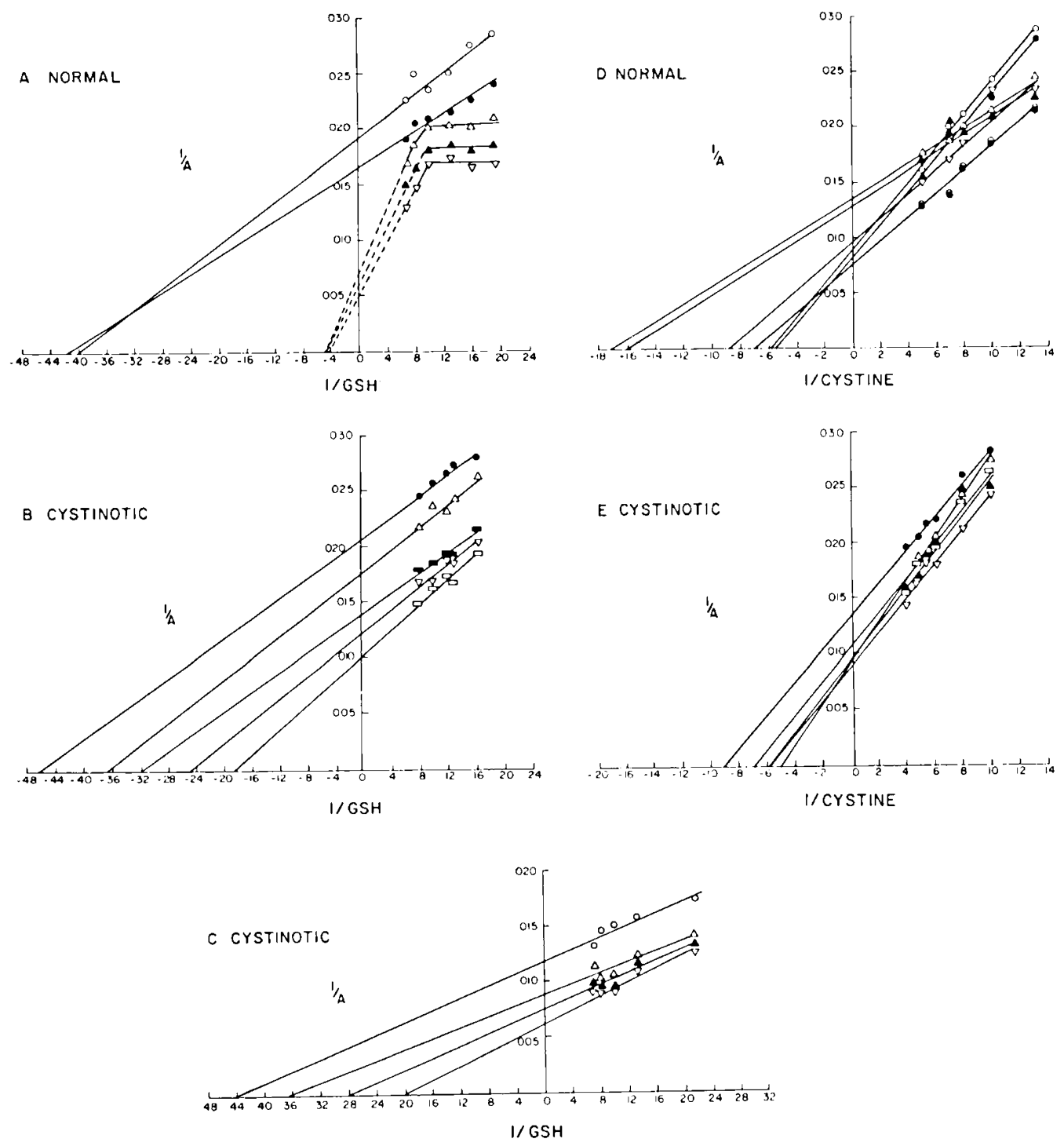

Fig. 1. Lineweaver-Burk plots of rates of cystine reduction. Assay conditions are described in text under "Methods": 1/reduced glutatione (GSH) and $1 /$ cystine are expressed per millimolar concentration; 1/A is expressed as $1 /$ micromolar concentration of cystine reduced to cysteine/10 min $\cdot$ mg protein]. $A, B$, and $C$ cystine concentrations are $0,76 \mu \mathrm{M} ; \bullet, 100 \mu \mathrm{M} ; \triangle, 126 \mu \mathrm{M} ; \mathbf{\Lambda}, 152 \mu \mathrm{M}, \mathbf{D}, 164 \mu \mathrm{M}, \boldsymbol{\nabla}, 200 \mu \mathrm{M} ; \square, 252 \mu \mathrm{M}$. D and E GSH concentrations are $O, 53 \mu \mathrm{M} ; \bullet, 61 \mu \mathrm{M} ; \triangle, 76 \mu \mathrm{M} ; \square, 83 \mu \mathrm{M} ; \Delta, 99 \mu \mathrm{M} ; \mathbf{\nabla}, 122 \mu \mathrm{M} ;$ and $\boldsymbol{\odot}, 137 \mu \mathrm{M}$. The data shown in $A$ and $D$ were obtained from a typical normal cell line. Cells used in $B$ and $E$ contained $13 \mu$ mol half-cystine/g protein and cells used in $C$ contained $14 \mu \mathrm{mol}$ halfcystine/g protein.

$\mu$ mol half-cystine/g protein. Although the two-limbed curve seen with normal cells was not present the lines obtained with increasing amount of cystine were not parallel and the same $K_{m}$ for GSH was obtained. A second cell line from this patient grown from a biopsy when he was 3 years old was also studied and the results are shown in Figure $2 B$. These cells, which contained $14 \mu \mathrm{mol}$ half-cystine/g protein, showed a similar pattern to those of the earlier cell line from the patient except for apparent substrate inhibition.

The complexities of the enzymatic reduction of cystine and the nonenzymatic oxidoreduction of the GSH-cystine system have been studied extensively with emphasis on the initial ratios of cystine and GSH $(4,5)$. Of course, in studies where one substrate is varied, the ratios of the two are changing constantly. Therefore, data from Lineweaver-Burk plots under constant GSH and varying cystine concentrations were replotted as activity against increasing cystine concentrations at ratios of cystine to GSH of $1: 2,1: 1$, and $2: 1$ to determine whether the cystine to GSH ratio affects the patterns of enzymatic reduction of cystine to cysteine (Fig. 3). Figure $3, A$ and $B$, shows plots in which the ratios of cystine to GSH are $1: 2$ and $1: 1$, respectively. These two figures show the increasing rate of cystine reduction by one normal line and three lines with high intracellular cystine. At these cystine to GSH ratios, two of the three lines from cystinotics reduce cystine at a faster rate than the normal line. The third line from a cystinotic appears to reduce cystine at a slightly slower rate when the substrate concentration in the assay is less than $80 \mu \mathrm{M}$ cystine. However, with this third cell line, the rate of eystine reduction is comparable to the normal lines when the cystine to GSH ratio is $1: 1$ and the cystine concentration is above $80 \mu \mathrm{M}$.

Figure $3 C$ is a plot of one normal line and six lines from cystinoties when the cystine to GSH ratio is maintained at $2: 1$. In this plot, only the normal cells show a stepwise pattern for cystine reduction. There is a linear increase in the rate of cystine reduction up to $100 \mu \mathrm{M}$ cystine. No increase in the rate occurs from $100 \mu \mathrm{M}$ to $200 \mu \mathrm{M}$ cystine; however, an increase in the rate resumes when the concentration of cystine in the incubation 

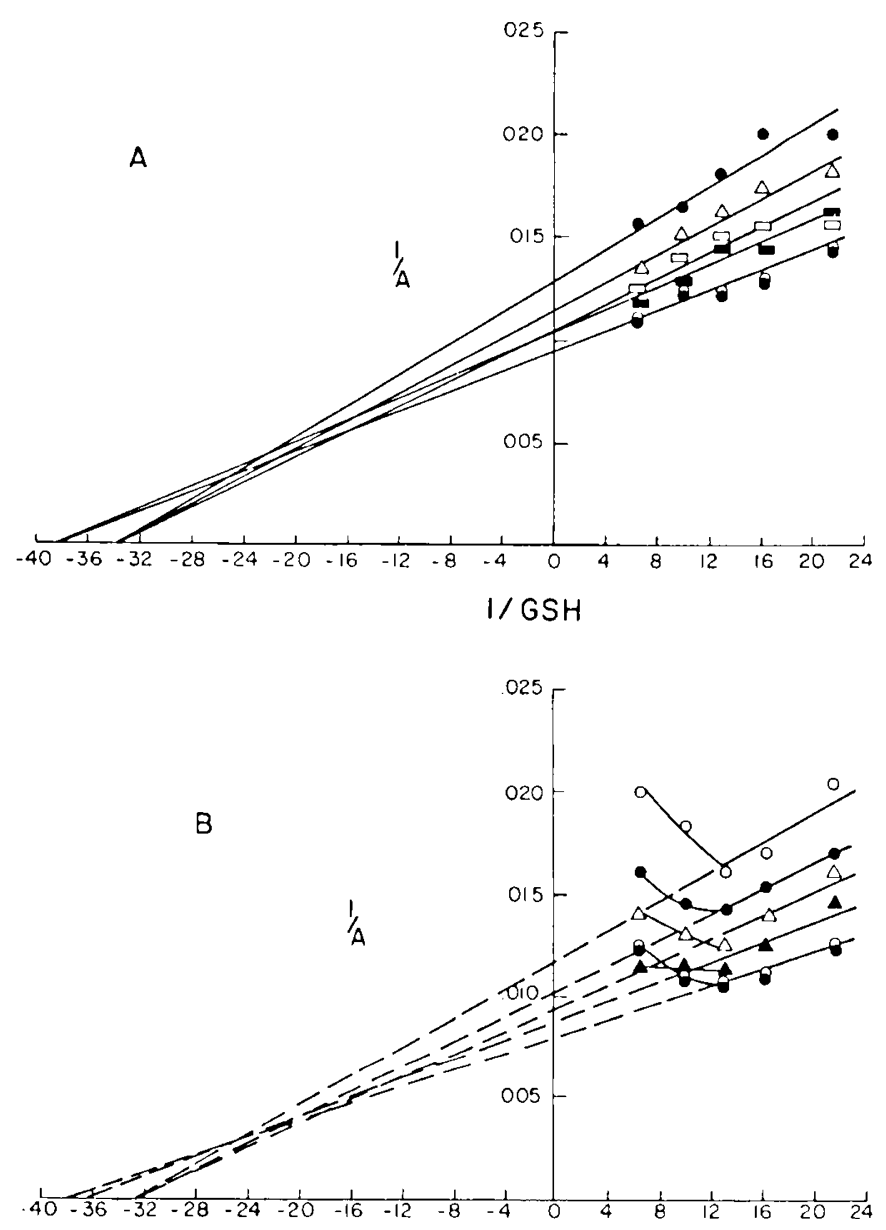

I/GSH

Fig. 2. Lineweaver-Burk plots of rate of cystine reduction from two cell lines obtained from one eystinotic patient. Conditions of assay are described in text under "Methods": 1/GSH and 1/cystine are expressed per millimolar concentration; $1 / \mathrm{A}$ is expressed as 1 (micromolar concentration of cystine reduced to cysteine/10 min $\cdot \mathrm{mg}$ protein). Cystine concentrations are $\bigcirc .76 \mu \mathrm{M} ; \bullet, 100 \mu \mathrm{M} ; \triangle, 126 \mu \mathrm{M} ; \mathbf{\Delta}, 152 \mu \mathrm{M} ; \square$, $164 \mu \mathrm{M} ; \mathbf{0}, 182 \mu \mathrm{M}$; and $0,200 \mu \mathrm{M}$. Cells used to obtain the data contained $6.5 \mu \mathrm{mol}$ half-cystine/g protein $(A)$ and $13.5 \mu \mathrm{mol}$ halfcystine/g protein $(B)$.

is raised above $200 \mu \mathrm{M}$. Such a stepwise configuration is absent from plots of data from studies with the six cell lines containing more than $6 \mu \mathrm{mol}$ half-cystine/g cellular protein.

\section{DISCUSSION}

In the past, cystine reduction has been determined by an indirect assay method in which the oxidation of exogenous NADPH by yeast GSSG reductase is coupled to the combined reduction of cystine and oxidation of GSH by the enzymes in the cystine reductive pathway. In our studies, the amount of L$\left[{ }^{35}\right.$ S $]$ cystine reduced to L-[ $\left.{ }^{35} S\right]$ cysteine by enzyme(s) within the cytosol was determined directly without the addition of exogenous GSSG reductase. Hence, the regeneration of GSH from GSSG in the presence of added NADPH depended entirely on the activity of the endogenous GSSG reductase and not on the presence of exogenous yeast GSSG reductase. Such a system provides a truer picture of the intrinsic capability of the cell to reduce cystine and regenerate GSH.

Our studies of cystine reduction by cells from normal and cystinotic subjects corroborate the presence of an enzymatic pathway which carries out the reduction of cystine by supernatants of cell extracts as reported by Tietze et al. (24) and Kaye and Nadler (6). However, our results show that specific differences exist in the manner in which fibroblasts from normal and cystinotic subjects handle cystine in the presence of high concentrations of both cystine and GSH. The concentration of GSH has a profound effect upon the rate of cystine reduction in cells from normal subjects and patient cells with intracellular eystine under $6 \mu \mathrm{mol}$ half-cystine/g protein. In incubations where GSH levels are increased in the presence of high levels of cystine (Fig. $1 A$ ), the maximum velocity doubles and the $K_{m}$ decreases 10 -fold. In contrast, Lineweaver-Burk plots of the results from studies with extracts from cell lines containing $6-14 \mu \mathrm{mol}$ intracellular halfcystine/g protein show a minimal increase in maximum velocity with either no change or only a small increase in the apparent $K_{m}$. There are differences also within these six cell lines from the cystinotic patients. Four of them reduce cystine at a faster rate than normal cells. Two lines, initiated from the same cystinotic patient, show no increase in the $K_{m}$ for GSH as the cystine concentration is increased.

At least two aspects of heterogeneity are operative within the lines from cystinotic patients. The first related to variations in the clinical manifestations of the disease within the same group of cystinotic patients (16). Such clinical variations could be caused by multiple factors and be expressed in the cells initiated from biopsies from different patients. The second aspect is the inherent heterogeneity in the cell line itself (7). Each line represents a mixed fibroblast population and subculturing could lead to the natural selection of cells with much lower levels of intracellular cystine. If eells with low cystine levels were to become dominant in a cystinotic line, one could expect a pattern of cystine reduction comparable to normal cell lines.

Although the complexities of a system with at keast two $k_{m}$ and two $V_{\text {max }}$ values (Figs. IC, 3C) cannot be defined without further resolution of the several enzymes involved, the studies of Pihl and Eldjarn (14) suggest that as the ratio of cystine to GSH increases, e.g., from $1: 2$ to $2: 1$, more cysteine and L-cysteineglutathione (CSSG) accumulate. At the point where the ratio of cystine to GSH is 2:1, equimolar quantities of cystine, CSSG, and cysteine are present. However, in a crude enzyme preparation, the excess GSH present at a 1:2 ratio of cystine to GSH reacts through enzymatic thiol-disulfide interchange with CSSG. The two-step reaction is

$$
\begin{aligned}
& \mathrm{CSSC}+\mathrm{GSH} \rightleftharpoons \mathrm{CSSG}+\mathrm{CSH} \\
& \mathrm{CSSG}+\mathrm{GSH} \rightleftharpoons \mathrm{GSSG}+\mathrm{CSH}
\end{aligned}
$$

An enzyme which reduces L-cysteine-glutathione in the presence of GSI has been purified $20(0$-fold from rat liver by Mannervik and Axelsson (9) and has been separated from GSSG reductase and other thioltransferases by column chromatography. Whether this enzyme differs from the GSH-cystine transhydrogenase which purportedly catalyzes the reduction of cystine is not clear. With the production of GSSG and addition of NADPH, the GSSG reductase activity in the crude preparation regenerates GSH. The widely distributed GSSG reductase has been studied in rat organs and human red cells and been shown to be highly active $(2,10,18,19)$.

When the cystine in the incubation is increased and the ratios of cystine to GSH are raised to 1:1 (Fig. 3B) or 2:1 (Fig. 3C), reduction of CSSG, produced in the first step of cystine reduction, could play a key role in the capacity of the cell to utilize cystine. As shown in step $b$, when GSH availability becomes severely limited, reduction of CSSG could be the rate-limiting step in cysteine formation from cystine. An alternative pathway to regenerate the GSH required for further eystine reduction would be the direct reduction of the mixed disulfide, CSSG, in the presence of NADPH. This could be accomplished either by GSSG reductase or by an enzyme which remains to be elucidated. Carlberg and Mannervik (2) have reported that purified rat liver glutathione reductase slowly reduces CSSG. If such a reduction were functional in normal cells under conditions of excessive accumulation of CSSG, the regeneration of GSH 

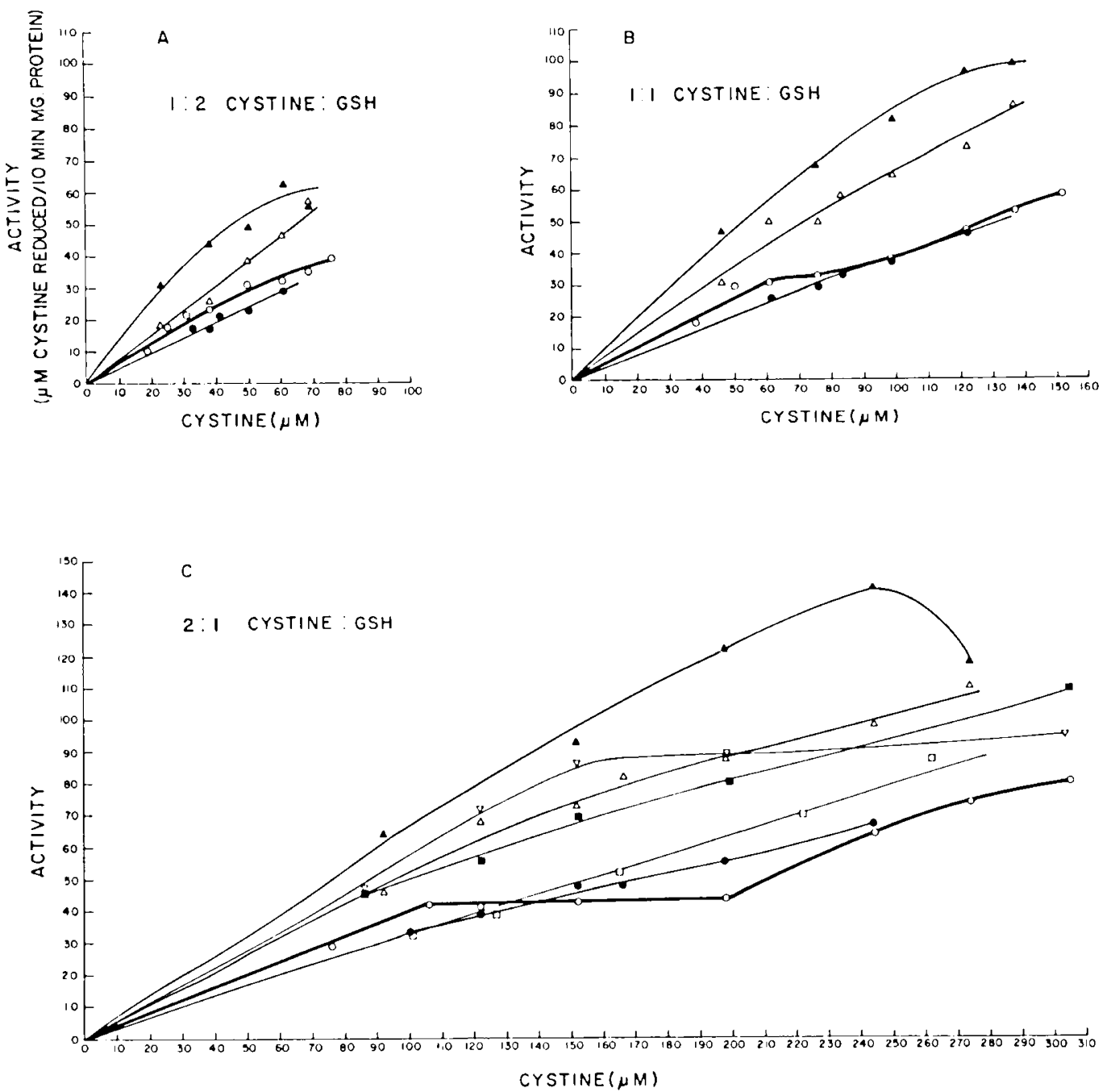

Fig. 3. Plot of data under conditions of constant cystine to reduced glutathione ratios. Conditions of assay are described in text under "Methods". Cells from normal line $(O)$; cells initiated from cystinotics with cell lines containing $13 \mu$ mol half-cystine/g protein $(\Delta) ; 14 \mu \mathrm{mol}$ half-cystine/g protein $(\nabla) ; 9 \mu \mathrm{mol}$ half-cystine/g protein $(\triangle) ; 7 \mu \mathrm{mol}$ half-cystine/g protein (D); $10.8 \mu \mathrm{mol}$ half-cystinc/g protein (D); and $14 \mathrm{~mol}$ half-cystine/g protein (O).

would result in continued reduction of excess cystine to cysteine, i.e.:

$$
\begin{aligned}
\mathrm{CSSG}+\mathrm{NADPH}+\mathrm{H}^{+} & \rightleftharpoons \mathrm{GSH}+\mathrm{CSH}+\mathrm{NADP}^{+} \\
\mathrm{CSSC}+\mathrm{GSH} & \rightleftharpoons \mathrm{CSSG}+\mathrm{CSH}
\end{aligned}
$$

The differences in the pattern of cystine reduction by enzymes within the cytosol of normal cells and cells with high intracellular cystine cannot be attributed to elevated levels of endogenous free GSH in the latter. The concentration of free intracellular GSH in fibroblasts from normal and cystinotic children range from 6-25 $\mu \mathrm{mol}$ GSH $/ \mathrm{g}$ cellular protein. Up to the present time, no significant differences in GSH levels in the two cell types have been reported $(12,18)$.

The loss of control of cystine reduction could explain our previous findings (3) that fibroblasts with high levels of intracellular cystine had the same apparent transport $K_{1}$ but higher maximum velocity of transport than normal fibroblasts. Normal cells could have a control mechanism which, under conditions of cystine stress, would become operative. Some investigators (4, 11) have evidence to suggest that excessive production of intracellular disulfides can result in the increased tendency for mixed disulfide formation with essential thiol groups of enzymes. Patrick (13) has shown that when cystine is added to homogenates of normal liver and kidney, the activities of sulfhydryl-dependent enzymes are reduced markedly as compared with control homogenates. Addition of - SH compounds restores activity, suggesting that the inhibition is easily reversed. However, Patrick did not investigate the role of CSSG in the apparent toxicity of cystine.

The formation of L-cysteine-glutathione in normal cells could act as a shut-off valve against reduction of cystine until CSSG could be metabolized. In cells with high levels of cystine, such a mechanism of control could be either absent, altered, or defective. The absence of a stepwise pattern suggesting a loss of control over the rate of cystine reduction by cells from cystinotic subjects could be either a primary factor leading to eventual cystine accumulation or a secondary factor in that the cell, in starving to rid itself of exeess cystine, loses control over cystine reduction. However, the reported unavailability of the sequestered cystine in cells from cystinotic subjects under cystine privation $(12,17)$ would lead one to believe that the compartmentalization of eystine is such that it would exert only a minor influence on the reduction of free cystine. This fact must be weighed against the fact that lines with low levels of intracellular cystine show a pattern of cystine reduction typical of normal subjects.

Many additional kinetic parameters starting with delineation of the multistep reduction of eystine remain to be investigated thoroughly before a correlation can be established between the patterns of cystine reduction in fibroblasts from cystinotic pa- 
tients, cystine accumulation, and cystinosis. Such studies now are underway.

\section{CONCLUSION}

Studies were undertaken to re-evaluate cystine reduction by fibroblasts initiated from normal and cystinotic patients. The assay involved direct determinations of the rates of cysteine formation from L-[35 S|cystine by the multienzyme systems present in the $105.000 \times$ g supernatant after cell fractionation. A difference between the two cell types was the stepwise pattern of cystine reduction at a cystine to GSH ratio of 2:1 observed with extracts from normal cells but not with cells containing more than $6 \mu$ mol half-cystine/g protein. Of the six cell lines with high intracellular half-cystine studied, four reduced cystine at a faster rate than the normal lines. Our results suggest that normal cells have a control mechanism which may be absent, altered, or defective in cells with high levels of intracellular cystine.

\section{REFIEREN(ISS ANI) NOTES}

1. Askelof, P., Axelsson, K. Eriksson, $S$, and Nannervik, B. Mechanism of action of enzymes catalyzing thiol-disulfide interchange: Thioltransferases ratther than transhydrogenases. FEBS Lett., 38: 26.3 (1974).

2. Carlberg, I., and Mannervik, B.: Purification and characterization of the flavoenzyme glutathione reductase from rat liver. J. Biol. Chem., 250: 5475 (1975).

3. Eriksson, S. A., and Mannervik, B.: The reduction of the L-cysteine-glutathione mixed disulfide in rat liver. Involvement of an enzyme catalyzing thioldisulfide interchange. FIBSS Lett. 7: 26 (1970).

4. Gorin, G., and Doughty, G.: Equilibrium constants for the reaction of glutathione with eystine and their relative oxidation-reduction pertentials. Arch. Biochem. Biophys., 126: 547 (1968).

5. Jocelyn, P. C.: The standard redox potential of cysteine-cystine from the thioldisulphide exchange reaction with glutathione and lipoic acid. Europ. J. Biochem., 2: 327 (1967).

6. Kaye, I. C., and Nadler, H. L.: Inzymic reduction of eystine and glutathione in cultivated human fibroblasts from normal subjects and patients with cystinosis. J. Lab. Clin. Med., 86: 422 (1975).

7. Kruse, P. F., Jr., and Patterson, M., Jr.: Single Cell Isolations and Cloning. In: Tissue Culture, methods and applications, p. 235 (Academic Press, New York, 1973)

8. Lowry, O. H., Rosebrough, N. I:., Farr, A. L., and Randall, R. J.: Protcin measurement with the Folin phenol reagent. J. Biol. Chem., 193: 265 (1951).

9. Mannervik, B., and Axelsson, K.: Reduction of disulphide bonds in proteins and protein mixed disulphides cattalyzed by a thioltransferase in rat liver cytosol. Biochem. J.. 149: 785 (1975).

10. Mize, C. E., and Langdon, R. G.: Hepatic glutathione reductase 1. Purificattion and general kinctic properties. J. Biol. (hem., 237: 1589 (1962).

11. Modig. H.: Cellular mixed disulphides between thiols and proteins and their possible implication for radiation protection. Biochem. Pharmacol.. 17: 177 $(1968)$.

12. Oshima, R. G., Rhead, W. J., Therene, J. G., and Schncider, J. A.: Cystine metabolism in human fibroblasts. J. Biol. (hem., 251: 4287 (1976)

13. Patrick, A. D.: Deficiencies of SH-dependent enzermes in cystinosis. Clin. Sci., 28: $427(1965)$.

14. Pihl, A.. and I:ldjarn, L.: Fourth International Congress of Biochemistry, Vienna 1958. Vol. XIII, p. 43, Colloquia, Macmillan, New York (Pergilmon Press, 1959).

15. Pontremoli, S., Traniello, S., Enser, M., Shapiro, S., and Horecker, B. L.: Regulation of fructose diphosphatase activity by disulfide exchange. Proc. Natl. Sci. USA, 58: 286 (1967).

16. Schneider, J. A.: Clinical Aspects of Cystinosis. In: J. D. Schulman: Cystinosis, DHLW Publication No. (NIH) 72-249, Chapt. 2, p. 11 (U.S. Govermment Printing Office, Washington, D.C., 1972).

17. Schneider, J. A., Rosenbloom, F. M1., Bradley, K. H., and Seegmiller, J. E.: Increased free-cystine content of fibroblasts cultured from patients with cystinosis. Biochem. Biophys. Res. Commun.. 29: 527 (1967).

18. Schuiman. J. D.. Schneider, J. A., Bradley, K. H., and Secomiller, J. E Cystine, cysteine, and glutathione metabolism in normal and cystinotic fibroblasts in vitro and in cultured normal ammiotic fluid cells (lin. Chim Actia, 35: 383 (1971).

19. Srivastava, S. K., and Beutler, E.: Glutathione metabolism of the erythrocyte Biochem. J., 119: $353(1970)$

20. Staal, G. E. J., Visser, J., and Veeger, C.: Purification and properties of glutathone reductase of human erythrocytes. Biochim. Biophys. Acta, 185 : $39(1969)$.

21. States, B., Harris, D., and Scgal, S.: Uptate and utilization of exogenous cystine by cystinotic and normal fibroblasts. J. Clin. Invest., 53: 100.3 (1974).

22. States, B., and Segal, S.: Thin-layer chromategraphic separation of cystine and the N-ethylmaleimide adducts of cysteine and glutathione. Anal. Biorchem. 27: $323(1969)$

23. States, B., and Segal, S.: Interrelationship of glutathione-cystine transhydrogenase and glutathione reductase in developing rat intestine. Biochem. J., 132: $623(1973)$.

24. Tietze, F., Bradley, K. H., and Schulman, J. D.: Enzymic reduction of cystine by subcellular fractions of cultured and peripheral leuhocytes from normal and cystinotic individuals. Pediat. Res., 6: 6.49 (1972)

25. This research was supported by Grant $A M 13900$ from the National Institute of Heialth. Bethesda, Mld.

26. The authors gratefully acknowledge the ecchnical assistance of Bonnic Yost for cystinc assays with a Beckman model $120 \mathrm{C}$ amino acid analyzer.

27. Requests for reprints should be addressed to: Beatrice States, Ph.l . Children's Hospital of Philadelphia, 34 th and Civic Center IBlvd., Philadelphia, Pa. 19104 (USA).

28. Received for publication July 13, 1976.

29. Accepted for publication October 20, 1976.

Copyright a) 1977 International Pediatric Rescarch Foundation, Inc.

Printed in U.S.A. 